\title{
Free Radical Scavenging Activity of Solanum trilobatum Linn. on Alloxan - Induced Diabetic Rats
}

\author{
A Doss* and SP Anand \\ PG \& Research Department of Botany, National College (Autonomous), Tiruchirappalli- 60001, Tamil Nadu, India
}

\begin{abstract}
Solanum trilobatum is reported to have a wide range of biological activities such as antidiabetic, antibacterial, antifungal, antimitotic, antioxidant, antitumours and is used for treatment of asthma, to arrest blood vomiting and several kinds of leprosy. In the present study, we report the effect of ethanol extracts of S.trilobatum leaf on free radical scavenging activity, in alloxan induced diabetic rats. The lipid peroxidation, superoxide dismutase and catalase were measured in liver homogenate, and Serum Glutamic Pyruvic Transaminase (SGPT), Serum Glutamic Oxaloacetic Transaminase (SGOT), cholesterol and glucose were measured in blood serum. Oral administration of single dose of alloxan monohydrate $(1 \mathrm{mg} / \mathrm{kg}$ ), caused significant increases in Lipid Peroxidation (LPO), SGOT, SGPT and glucose levels, while Superoxide Dismutase (SOD) and Catalase (CAT) levels were significantly decreased. Further, the administration of ethanol extracts of S.trilobatum leaf to alloxan induced diabetic rats, at a dose of 100 and $200 \mathrm{mg} / \mathrm{kg}$ orally for 10 days, led to a significant decrease in lipid peroxidation, SGPT, SGOT and cholesterol levels. Consequently, superoxide dismutase and catalase levels were significantly increased. Glibenclamide was used as a positive control $(10 \mathrm{mg} / \mathrm{kg})$. It was observed that the effect of ethanol extracts of S.trilobatum on cholesterol, superoxide dismutase, SGPT, SGOT levels, were compared to that of those produced by the positive control. The activities of SOD and CAT were found to be increased in extract treated diabetic rats in selected tissues. The increased level of lipid peroxidation in diabetic rats also was found to be reverted back, to near normal state in extract treated groups. Thus, it may be concluded that the ethanol extract of S.trilobatu, may produce its hypoglycemic effect through antioxidant defense mechanism.
\end{abstract}

Keywords: Antioxidant; Solanum trilobatum; Ethanol; SGOT; SGPT; CAT; SOD

\section{Introduction}

Diabetes Mellitus (DM) is a common metabolic disease, characterized by elevated blood glucose levels, resulting from absent or inadequate pancreatic insulin secretion, with or without impairment of insulin action. Such a deficiency results in increased concentrations of glucose in the blood, which in turn damages many of the body's systems, in particular the blood vessels and nerves [1]. It is the most prevalent disease in the world, affecting $25 \%$ of population and afflicts 150 million people, and is set to rise to 300 million by 2025 [2]. In India, it is estimated that presently 19.4 million individuals are affected by diabetes, and the figure is likely to go up to 57.2 million by the year 2025 [3]. Hyperglycemia alone does not cause diabetic complications. It is rather, the detrimental effect of glucose toxicity due to chronic hyperglycemia, mediated and complicated through augmented oxidative stress [4]. Hyperglycemia increases the production of reactive oxygen species (ROS) inside the aortic endothelial cells. ROSinduced activation of protein kinase- $\mathrm{C}$ isoforms, increased formation of glucose-derived advanced glycation end products, increased glucose flux through aldose reductase pathways and activation of cytokines are some of the known biochemical mechanisms of hyperglycemiainduced tissue and cell damage [2]. Many traditional medicinal plants that possess substantial quantity of antioxidant components have been found to be useful against diabetes and its related complications [5]. Hence, there is a huge prospect of development of potential hypoglycemic agent coupled with antioxidant activity, from traditional medicinal plants to combat diabetes and its complications. Apart from currently available therapeutic options, many herbal medicines have been recommended for the treatment of diabetes. Traditional plant medicines are used throughout the world, for a range of diabetic presentations. Solanum trilobatum (Solanaceae), a thorny creeper with bluish violet flowers, more commonly available in Southern
India has been used traditionally in Siddha system of medicines, to treat various diseases. Popularly called 'ththuvali' by the local tribes, villagers and herbalogists in Tamilnadu, this ethnobotanical herb in known to have unique medicinal properties [6]. It has been widely used to treat respiratory disorders, especially bronchial asthma [7]. It has hepatoprotective activity [8], antibacterial activity [9], antidiabetic activity [3] and antioxidant properties [10], and can treat several kinds of leprosy. Therefore, the present investigation was undertaken to evaluate, the role of ethanolic extract of S.trilobatum leaves (EEST), in effective management of diabetes through antioxidant defense mechanism.

\section{Materials and Methods}

\section{Plant material}

Mature leaves of S.trilobatum were collected, in the month of December 2008 from the villages; Coimbatore District, Tamilnadu, India. The plant was authenticated by the Botanical Survey of India (Southern Circle), Coimbatore District, Tamilnadu, India. A voucher specimen was deposited at our laboratory for future reference.

*Corresponding author: Doss A, PG \& Research Department of Botany, National College (Autonomous), Tiruchirappalli- 60001, Tamil Nadu, India, E-mail: androdoss@gmail.com

Received August 20, 2012; Accepted September 07, 2012; Published September 11,2012

Citation: Doss A, Anand SP (2012) Free Radical Scavenging Activity of Solanum trilobatum Linn. on Alloxan - Induced Diabetic Rats. Biochem Anal Biochem 1:115. doi:10.4172/2161-1009.1000115

Copyright: ( 2012 Doss A, et al. This is an open-access article distributed under the terms of the Creative Commons Attribution License, which permits unrestricted use, distribution, and reproduction in any medium, provided the original author and source are credited. 


\section{Preparation of extract}

The plant was dried under shade and powdered to coarse particles. The $2 \mathrm{~kg}$ powdered plant material was defatted, with petroleum ether $\left(60-80^{\circ} \mathrm{C}\right)$ in a Soxhlet extraction apparatus and further, the same amount plant material extracted with ethanol. The ethanol extract, S.trilobatum (EEST) was selected for the present study.

\section{Animals}

Wister albino rats (150-200gm) of either sex were procured from RVS Pharmaceutical College, Coimbatore, Tamilnadu. Before and during the experiment, rats were fed with standard diet (Lipton India Ltd). After randomization into various groups and before initiation of experiment, the rats were acclimatized for a period of 7 days at standard environmental conditions of temperature, relative humidity and dark/ light cycle. ( $12 \mathrm{~h}$ light or $12 \mathrm{~h}$ dark cycle, $25 \pm 3^{\circ} \mathrm{C}, 35-60 \%$ humidity). The experiments were conducted according to the ethical norms, approved by the Institutional Animal Ethical Committee guidelines of RVS Pharmaceutical College, Coimbatore (Approval No: IAEC1012/ C06/CPSEA- Coreres- 2008-2009).

\section{Induction of diabetes}

The Group II, III, IV and V animals were then anesthetized with Alloxan monohydrate $(120 \mathrm{mg} / \mathrm{kg})$, which was dissolved in saline immediately before use, and injected intraperitoneally. After 2 days, rats with moderate diabetes having glycosuria, indicated by Benedict's qualitative test and moderate hyperglycemia $(180-200 \mathrm{mg} / \mathrm{dl})$ were used for the experiment.

\section{Experimental design}

Animals were divided into five groups of six rats each. Group I: normal rats administered distilled water, $2.0 \mathrm{ml} / \mathrm{kg}$, orally daily for 10 days. Group II: diabetic control rats, administered $0.2 \mathrm{ml}$ of $2 \%$ aqueous gum acacia. Group III: diabetic rats administered EEST, $100 \mathrm{mg} / \mathrm{kg}$, orally daily for 10 days. Group IV: diabetic rats administered EEST, $200 \mathrm{mg} / \mathrm{kg}$, orally daily for 10 days. Group V: diabetic rats administered standard drug glibenclamide $(10 \mathrm{mg} / \mathrm{kg}$, orally) daily for 10 days. Body weights of experimental rats were measured on days 3, 5, $7 \& 10$. After 10 days of treatment, all the rats were anaesthetized and sacrificed by cervical dislocation; liver was excised and washed thoroughly to clear off blood. The tissues were immediately transferred to ice-cold saline and homogenized in $0.1 \mathrm{~N}$ Tris- $\mathrm{HCl}$ buffer ( $\mathrm{pH}$ 7.4).

\section{Preparation of liver homogenate}

The liver was weighed and 10\% liver homogenate was prepared with $0.1 \mathrm{M}$ phosphate buffer ( $\mathrm{pH} 7.0$ ), after centrifugation at 1000 $\mathrm{rpm}$ for $15 \mathrm{~min}$. The supernatant was used to measure protein, Lipid Peroxidation (LPO), SOD and CAT.

\section{Biochemical evaluations}

The blood serum, glucose [11], SGPT \& SGOT [12], cholesterol [13] and liver glycogen

\section{Protein content}

The protein content was estimated using a previously reported method [14]. Liver homogenate was mixed $(1.0 \mathrm{ml})$ with $2.25 \mathrm{ml}$ of $90 \%$ alcohol, and centrifuged at $3000 \mathrm{rpm}$ for $10 \mathrm{~min}$. The supernatant was discarded and the precipitate was dissolved in $1 \mathrm{ml}$ of $0.1 \mathrm{~N} \mathrm{NaoH}$, to which $1 \mathrm{ml}$ of alkaline mixture was added; set aside for $10 \mathrm{~min}, 0.5 \mathrm{ml}$ of folin reagent was added, and again set aside for $10 \mathrm{~min}$ for complete color development. The absorbance was measured at $610 \mathrm{~nm}$. Protein levels were calculated using standard bovine serum solution, $200 \mathrm{mg}$ in $100 \mathrm{ml}$ of distilled water.

\section{Lipid peroxidation}

Lipid peroxidation was estimated by the method [15]. Liver homogenate mixed $(1.0 \mathrm{ml})$ with $100 \mu \mathrm{l}$ of $8.1 \%$ sodium dodecyl sulfate (SDS), and $600 \mu \mathrm{l}$ of $20 \%$ acetic acid solution was kept for $2 \mathrm{~min}$ at room temperature, then $600 \mu \mathrm{l}$ of $0.8 \%$ solution of TBA, was added, heated at $95^{\circ} \mathrm{C}$ for $60 \mathrm{~min}$ in water bath and cooled with ice cold water at $4^{\circ} \mathrm{C}$. The mixtures of n-butanol, and pyridine $(15: 1, \mathrm{v} / \mathrm{v})$ were added, shaken vigorously and centrifuged at 10,000 $\mathrm{rpm}$ for $5 \mathrm{~min}$. The absorbance of the organic layer was measured at $532 \mathrm{~nm}$. Lipid peroxidation was expressed as nmoles of $\mathrm{MDA} / \mathrm{mg}$ of protein.

\section{Superoxide dismutase}

The SOD was estimated by the method [16,17], based on the reduction of Nitro Blue Tetrazolium (NBT) to water insoluble blue formazan. Liver homogenate $(0.5 \mathrm{ml})$ was taken, and $1 \mathrm{ml}$ of $50 \mathrm{mM}$ sodium carbonate, $0.4 \mathrm{ml}$ of $24 \mu \mathrm{m} \mathrm{NBT}$, and $0.2 \mathrm{ml}$ of $0.1 \mathrm{mM}$ EDTA was added. The reaction was initiated by adding $0.4 \mathrm{ml}$ of $1 \mathrm{mM}$ hydroxylamine hydrochloride. Zero time absorbance was taken at 560 $\mathrm{nm}$, followed by $5 \mathrm{~min}$ at $25^{\circ} \mathrm{C}$. The control was simultaneously run without liver homogenate. Units of SOD activity was expressed as, the amount of enzyme required to inhibit the reduction of NBT by $50 \%$. The specific activity was expressed in terms of units/mg of protein.

\section{Catalase}

Catalase was estimated using a previously reported method [18]. The reaction mixture contained $1.0 \mathrm{ml}$ of $0.01 \mathrm{M}$ Phosphate buffer ( $\mathrm{pH} 7.0$ ), $0.1 \mathrm{ml}$ of liver homogenate, and $0.4 \mathrm{ml}$ of $2 \mathrm{M} \mathrm{H}_{2} \mathrm{O}_{2}$. The reaction was stopped by the addition of $2.0 \mathrm{ml}$ of dichromatic-acetic acid reagent. The control was carried out without addition of $\mathrm{H}_{2} \mathrm{O}_{2}$, and then absorbance was read at $620 \mathrm{~nm}$. CAT activity was expressed as $\mu \mathrm{M}$ of $\mathrm{H}_{2} \mathrm{O}_{2}$ consumed $/ \mathrm{min} / \mathrm{mg}$ protein.

\section{Statistical analysis}

All the values of the present study were expressed as mean \pm standard error of mean (S.E.M.) and analyzed for ANOVA and post hoc Dunnet's T-test. Differences between groups were considered significant at $\mathrm{p}<0.05, \mathrm{p}<0.01, \mathrm{p}<0.001$ levels.

\section{Results}

Table 1 depicts the effect on rats with alloxan and treatment of ethanol extracts of Solanum trilobatum leaves (100 and $200 \mathrm{mg} / \mathrm{kg}$ ) on the levels of LPO, SOD, CAT activity in liver homogenates. The values obtained clearly reveal that LPO, SGPT, SGOT, glucose and cholesterol were significantly $(\mathrm{P}<0.001)$ reversed, by administration of Solanum trilobatum extracts in alloxan induced diabetic rats for 12 days. Consequently, the levels of SOD and CAT were significantly $(\mathrm{P}<$ 0.001) improved, after administration of Solanum trilobatum extracts in alloxan induced diabetic rats.

The blood serum of treated and control rats was used, to estimate the SGPT, SGOT, cholesterol and glucose (Table 2). A significant difference was observed between normal and diabetic rats in fasting blood glucose level. Ethanol extract of S.trilobatum, at the doses of 100 and $200 \mathrm{mg} / \mathrm{kg}$ body weight, significantly lowered fasting blood glucose level, and exhibited maximum reduction of 148.0 and 136.8 on Day 10, respectively. The results were compared with standard 


\begin{tabular}{|c|c|c|c|c|}
\hline Treatments & CAT (Unit/mg of protein) & SOD (Unit/mg of protein) & LPO MDA (nmol/mg of protein) & Liver glycogen (mg/gm of fresh Tissue) \\
\hline Diabetic control & $153.9 \pm 0.1^{* * *}$ & $9.03 \pm 0.05^{* * *}$ & $18.47 \pm 0.05^{\star \star *}$ & $0.021 \pm 0.04^{* * *}$ \\
\hline${ }^{\mathrm{b}}$ Gliben $(10 \mathrm{mg} / \mathrm{kg})$ & $327.9 \pm 0.05^{* * *}$ & $15.8 \pm 0.11^{* * *}$ & $9.06 \pm 0.05^{* *}$ & $0.062 \pm 0.006^{* * *}$ \\
\hline Normal & $334.8 \pm 0.11$ & $19.9 \pm 0.1$ & $7.96 \pm 0.1$ & $0.068 \pm 0.01$ \\
\hline${ }^{\mathrm{a} E E S T}(100 \mathrm{mg} / \mathrm{kg})$ & $246.7 \pm 0.07^{* *}$ & $12.9 \pm 0.1^{* *}$ & $14.93 \pm 0.05^{*}$ & $0.05 \pm 0.004^{* *}$ \\
\hline${ }^{\mathrm{a} E E S T}(200 \mathrm{mg} / \mathrm{kg})$ & $277.9 \pm 0.11^{\star *}$ & $14.6 \pm 0.1^{* \star *}$ & $11.9 \pm 0.1^{* *}$ & $0.061 \pm 0.003^{* *}$ \\
\hline
\end{tabular}

aEthanol extract of Solanum trilobatum

${ }^{b}$ Glibenclamide (Standard Drug)

Values are expressed as mean $+\mathrm{SEM}, \mathrm{n}=6$ in each group. ${ }^{* *} \mathrm{P}<0.001$, significant when compared to diabetic control

Table 1: Effect of Solanum trilobatum leaf extracts on CAT, SOD LPO and Liver glycogen levels in alloxan induced diabetic rats.

\begin{tabular}{|c|c|c|c|}
\hline Treatments & Glucose $(\mathrm{mg} / \mathrm{dl})$ & Cholesterol $(\mathrm{mg} / \mathrm{dl})$ & SGOT $(\mathrm{U} / \mathrm{dl})$ \\
\hline Diabetic control & $221.1 \pm 1.5^{\star * *}$ & $112 \pm 1.8^{* *}$ & $320.1 \pm 0.1^{* * *}$ \\
\hline${ }^{b}$ Gliben $(10 \mathrm{mg} / \mathrm{kg})$ & $114.5 \pm 0.3^{* * *}$ & $92 \pm 3.4^{* *}$ & $118.9 \pm 0.05^{* * *}$ \\
\hline Normal & $108.4 \pm 0.5$ & $84 \pm 2.01$ & $62.06 \pm 0.05$ \\
\hline${ }^{a} E E S T(100 \mathrm{mg} / \mathrm{kg})$ & $126 \pm 1.9^{* *}$ & $104 \pm 2.0^{* *}$ & $61.36 \pm 3.0$ \\
\hline${ }^{a}$ EEST $200(\mathrm{mg} / \mathrm{kg})$ & $123.8 \pm 0.5^{* *}$ & $98.2 \pm 2.8^{* *}$ & $199.1 \pm 0.11^{* *}$ \\
\hline
\end{tabular}

${ }^{a}$ Ethanol extract of Solanum trilobatum

${ }^{\mathrm{b}}$ Glibenclamide (Standard Drug)

Values are expressed as mean $+\mathrm{SEM}, \mathrm{n}=6$ in each group. ${ }^{* *} \mathrm{P}<0.001$, significant when compared to diabetic control

Table 2: Effect of Solanum triolobatum leaf extracts on Serum, Glucose, Cholesterol, SGOT and SGPT levels in alloxan induced diabetic rats.

\begin{tabular}{|c|c|c|c|c|}
\hline \multirow{2}{*}{ Treatments } & \multicolumn{4}{|c|}{ Body weight profile (g) } \\
\hline & $3^{\text {rd }}$ Day & $5^{\text {th }}$ Day & $7^{\text {th }}$ Day & $10^{\text {th }}$ Day \\
\hline Diabetic Control & $154.95 \pm 2.1$ & $151.5 \pm 5.17$ & $148.83 \pm 1.7$ & $144 . .71 \pm 0.5$ \\
\hline bGliben (1 mg/kg) & $145.76 \pm 1.68$ & $146.85 \pm 5.54$ & $149.57 \pm 4.66$ & $150.09 \pm 5.09$ \\
\hline Normal Control & $142.48 \pm 2.0$ & $148.25 \pm 0.25$ & $155.14 \pm 0.54$ & $162.61 \pm 3.14$ \\
\hline${ }^{a} E E S T(100$ mg/kg) & $144.75 \pm 0.75$ & $150.33 \pm 3.42$ & $154.8 \pm 1.95$ & $159.63 \pm 0.92$ \\
\hline${ }^{a}$ EEST $(200$ mg/kg) & $149.61 \pm 2.52$ & $152.65 \pm 6.45$ & $156.55 \pm 1.55$ & $164.73 \pm 4.17$ \\
\hline
\end{tabular}

aEthanol extract of Solanum trilobatum

'Glibenclamide (Standard Drug)

Values are expressed as mean + SEM, $n=6$ in each group. ${ }^{* * *} \mathrm{P}<0.001$, significant when compared to diabetic controls

Table 3: Effect of EEST leaves on body weight profile of normal and diabetic rats.

oral hypoglycemic agent, glibenclamide $(10 \mathrm{mg} / \mathrm{kg})$, which exhibited maximum reduction of 124.5 on Day 10 (Table 2). Glibenclamide is often used as an insulin stimulant in many studies, and also used as a standard antidiabetic drug in alloxan induced moderate diabetes, to compare the antidiabetic properties of a variety of hypoglycemic compounds.

Significant decrease in the level of liver glycogen was observed in diabetic rats, when compared with normal control groups. Oral administration of EEST at the selected doses, significantly increases liver glycogen level to its normal level and the result is comparable, to that of standard drug glibenclamide (Table 1). Ethanol extract of S.trilobatum treatment also, improved body weight profile with respect to diabetic control group (Table 3). The findings of our study shows that, protection provided by Solanum trilobatum extracts could maintain the levels of LPO, SOD, CAT, biomarker enzymes (SGOT, SGPT), cholesterol and glucose in alloxan induced diabetic rats.

\section{Discussion}

Oxidative stress plays an important role in chronic complication of diabetes, and is postulated to be associated with increased lipid peroxidation. Alloxan is a toxic glucose analogue, which selectively destroys insulin-producing cells in the pancreas, when administered to rodents and many other animal species. This causes an insulindependent diabetes mellitus (called "Alloxan Diabetes") in these animals, with characteristics, similar to type1 diabetes in humans. Alloxan administration produced elevated level of lipid peroxidation, hydroperoxides and conjugated dienes, that is a clear manifestation of excessive formation of free radicals and activation of lipid peroxidation system resulting in tissue damage [19]. In the present study, diabetes control rats, exhibited significantly elevated fasting blood glucose and cholesterol levels, as compared with normal control rats. Treatment with EEST, significantly reduced fasting blood glucose and cholesterol levels. The significant control of plasma lipid levels, suggests that the extract may produce its action, by improving insulin secretion [20]. Diabetic rats exhibited significantly lower level of liver glycogen level, which was significantly reverted back near to the normal status in EEST treated diabetic groups, may be due to the reactivation of the glycogen synthase system by improving insulin secretion. Diabetes is associated with weight loss. Imbalance between energy intake and expenditure results in a change in body weight. Alloxan induced diabetic rats showed decreased level of body weight. The decrease in body weight in diabetic rats clearly shows a loss (or) degradation of structural proteins. Weight loss, which is one of the clinical features of diabetes mellitus, may be due to the degeneration of the energy lost from the body due to frequent urination and over conversion glycogen to glucose. This shows that, the plant extract the degeneration of the adiposite in adipose and muscle tissues which occurs during diabetic stress inorder to make up for every loss from the body due to frequent urination, over conversion of glycogen urination and over conversion to glucose [21].

The SOD and CAT are the two major scavenging enzymes that remove free radicals in vivo. A decreased activity of these antioxidants, can lead to an excess availability of superoxide anion $\left(\mathrm{O}_{2}{ }^{\mathrm{I}}\right)$ and 
hydrogen peroxide $\left(\mathrm{H}_{2} \mathrm{O}_{2}\right)$, which in turn, generate hydroxyl radicals $(\mathrm{OH})$, resulting in initiation and propagation of LPO. The SOD can catalyze dismutation of $\mathrm{O}_{2}{ }^{\mathrm{I}}$ into $\mathrm{H}_{2} \mathrm{O}_{2}$, which is then deactivated to $\mathrm{H}_{2} \mathrm{O}$ by catalase, or SOD works in parallel with selenium-dependent glutathione peroxidase, which plays an important role in the reduction of $\mathrm{H}_{2} \mathrm{O}_{2}$, in the presence of reduced glutathione forming oxidized glutathione, and it protects cell protein and cell membranes against oxidative stress. In our study, the SOD and CAT enzymes were significantly $(\mathrm{P}<0.001)$ decreased in alloxan induced diabetic control rats, may be due to inactivation caused by free radicals [22]. The SOD and CAT play a prominent role in scavenging free radical and restoring antioxidant activities in the tissue of diabetic animals [23]. The above observations may clearly suggest that, increased levels of SOD and CAT of Solanum trilobatum extracts has free radical scavenging activity, which may exert a beneficial effect against pathological alterations, caused by reactive oxygen species.

The elevation of biomarker enzymes, such as SGPT and SGOT was observed in diabetic control rats indicating the hepatic damage [24]. The diabetic complications such as increased gluconeogenesis and ketogenesis may be due to elevated transaminases activity [3]. There is significant decrease in serum cholesterol levels in Solanum trilobatum extract treated rats, as evident by reports exhibiting a potent hypocholesterolemic effect. However, the possible underlying mechanism is not elucidated at this stage of the study. The previous studies have reported that administration of Momordica charantia lead to decrease in cholesterol levels, probably by two mechanisms; one by decreasing absorption of cholesterol from intestine, by binding with bile acids within intestine and increasing the extraction of faecales bile acids, and the other by biosynthesis of cholesterol, especially by decreasing the activity of 3-hydroxyl-3-methly-glutaryl coenzymes A reductase (HMG CoA reductase), an enzyme of cholesterol biosynthesis [25]. Same mechanism may be appropriate to explain the observed cholesterol lowering activity by Solanum trilobatum extracts.

Natural antioxidant strengthens the endogenous antioxidant defenses from reactive oxygen species and restores an optimal balance by neutralizing the reactive species. They are gaining immense importance, by virtue of their critical role in disease prevention. In the present study, it is concluded that Solanum trilobatum extract has free radical scavenging activity and improved antioxidant effect. The precise mechanism(s) and site(s) of action, as well as, constituents of Solanum trilobatum will be further determined including their toxicological effects.

\section{References}

1. Nagappa AN, Thakurdesai PA, Venkat Rao N, Singh J (2003) Antidiabetic activity of Terminalia catappa Linn fruits. J Ethnopharmacol 88: 45-50.

2. Dewanjee S, Maiti A, Sahu R, Dua TK, Mandal V (2011) Effective Control of Type 2 Diabetes through Antioxidant Defense by Edible Fruits of Diospyros peregrina. Evid Based Complement Alternat Med 2011: 675397.

3. Doss A (2009) Antidiabetic activity of aqueous extract of Solanum trilobatum Linn. in alloxan induced diabetic albino rats. Res J Biol Sci 1: 20-25.

4. Mohamed AK, Bierhaus A, Schiekofer S, Tritschler H, Ziegler R, et al (1999) The role of oxidative stress and NF-kappaB activation in late diabetic complications. Biofactors 10: 157-167.

5. Resmi CR, Venukumar MR, Latha MS (2006) Antioxidant activity of Albizzia lebbeck (Linn.) Benth. in alloxan diabetic rats. Indian J Physiol Pharmacol 50: 297-302.

6. Doss A, Mubarack HM, Dhanabalan R (2009) Antibacterial activity of tannins from the leaves of Solanum trilobatum Linn. Indian J Sci Technol 2: 41-43.

7. Govindan S, Viswanathan S, Vijayasekaran V, Alagappan R (2004) Further studies on the clinical efficacy of Solanum xanthocarpum and Solanum trilobatum in bronchial asthma. Phytother Res 18: 805-809.
8. Shahjahan M, Sabitha KE, Mallika Devi R, Shyamala Devi CS (2004) Effect of medicinal plants on tumerogenesis. Ind J Med Res 123: 23-27.

9. Doss A, Rangasamydhanabalan (2008) Preliminary Phytochemical Screening and Antibacterial Studies of Leaf Extract of Solanum trilobatum Linn. Ethnobotanical leaflets 12: 638-642.

10. Shahjahan M, Vani G, Shyamaladevi CS (2005) Effect of Solanum trilobatum on the antioxidant status during diethyl nitrosamine induced and phenobarbital promoted hepatocarcinogenesis in rat. Chem Biol Interact 156: 113-123.

11. Dubowski KM (1962)An o-toluidine method for body fluid glucose determination. Clin Chem 8: 215-235

12. Reitman S, Frankel S (1957) Colorimetric method for the determination of serum transaminase activity. Am J Clin Path 18: 22-56.

13. Demacker PN, Hessels M, Toenhake-Dijkstra H, Baadenhuijsen H (1997) Precipitation methods for high density lipoprotein cholesterol measurement compared, and final evaluation under routine operating conditions of a method with a low sample-to-reagent ratio. Clin Chem 43: 663-668.

14. Lowry OH, Rosebrough NJ, Farr AL, Randall RJ (1951) Protein measurement with the Folin phenol reagent. J Biol Chem 193: 265-275.

15. Ohkawa H, Ohishi N, Yagi K (1979) Assay for lipid peroxides in animal tissues by thiobarbituric acid reaction. Anal Biochem 95: 351-358.

16. Beauchamp C, Fridovich I (1971) Superoxide dismutase: Improved assays and an assay applicable to acrylamide gels. Anal Biochem 44: 276-287.

17. Chidambara Murthy KN, Jayaprakasha GK, Singh RP (2002) Studies on antioxidant activity of pomegranate (Punica granatum) peel extract using in vivo models. J Agric Food Chem 50: 4791-4795.

18. Sinha AK (1972) Colorimetric assay of catalase. Anal Biochem 47: 389-394.

19. Sabu MC, Kuttan R (2004) Antidiabetic activity of Aegle marmelos and its relationship with its antioxidant properties. Indian J Physiol Pharmacol 48: 81 88.

20. Shirwaikar A, Rajendran K, Kumar C (2004) Oral antidiabetic activity of Annona squamosa leaf alcohol extract in NIDDM rats. Pharm Biol 42: 30-35.

21. Mude RN, Somesula SR, Adi PJ, Matcha B (2012) Diabetic Regulation through blood constituents' modulations on treatment with Aloe vera in Alloxan induced Diabetic Rats. Digest Journal of Nanomaterials and Biostructures 7: 649-655.

22. Rathod NR, Raghuveer I, Chitme HR, Chandra R (2009) Free Radical Scavenging Activity of Calotropis gigantea on Streptozotocin-Induced Diabetic Rats. Indian J Pharm Sci 71: 615-621.

23. Rathod NR, Raghuveer I, Chitme HR, Chandra R (2009) Free radical scavenging activity of Calotropis gigantea on Streptozotocin-induced diabetic rats. Indian J Pharm Sci 71: 615-621.

24. Selvan VT, Manikandan L, Senthil Kumar GP, Suresh R, Kakoti BB, et al. (2008) Antidiabetic and antioxidant effect of methanol extract of Artanema sesamoides in Streptatozocin-induced diabetic rats. International Journal of applied research in natural products 1.

25. Lemhadri A, Hajii L, Michel JB, Eddouks M (2006) Cholesterol and triglycerides lowering activities of caraway fruits in normal and streptozotocin diabetic rats. $J$ Ethnopharmacol 106: 321-326. 